\title{
Enhancing tax compliance among briefcase companies in Kenya
}

\author{
John Carrey Okore \\ (Department of Accounting and Finance, University of Nairobi, Kenya)
}

\begin{abstract}
KRA continues to struggle with enforcement of voluntary compliance amongst taxpayers. Various approaches have been adopted to try and solve the problems. The problem is however bigger and "Tenderpreneurs" continue to be a historic thorn in the flesh of the Authority and other government agencies. This paper proposes several approaches to mitigating this problem. Firstly, a flat simplified rate of tax of $20 \%$ based on the VAT to GDP ratio, tax to GDP ratio and benchmarked with the legal MRI rate of tax is proposed. Analysis of data from 26 counties reveals that had the law established such a system earlier, KRA would have collected at least Kes 8 billion for the financial year 2015/2016. The paper also proposes a Transaction-Based Income Tax as a mandatory tax type for all small taxpayers. Exemption from this regime to the formal regime is proposed to happen through a "Class A" certification, which is only given based on a satisfactory tax payment history for the taxpayer and execution of a tax bond modeled along what is used under the East African Community Customs Management Act 2004. The underlying principles in the suggestions are simplification of processes, corporate gatekeeping and virtual presence of KRA. It is proposed that should the proposals be found worthy of attention, rigorous risk analysis and impact assessments be conducted before application.
\end{abstract}

Keywords: Briefcase companies, TBIT, Tenderpreneurs, Class A Certification, Tax Bonds

\section{Introduction}

Established by the Kenya Revenue Authority Act Cap 469 of 1995, Laws of Kenya, the purpose of KRA is to be the central body for the assessment and collection of revenue, for the administration and enforcement of the laws relating to revenue and to provide for connected purposes. The various laws relating to revenue that are administered by the authority are listed in the first schedule to the said Act.

The Authority is also mandated under Section 78 of the Public Finance Management Act $2012^{[1]}$ to be the collector of national government revenue. Since inception, the Authority has undergone and is undergoing a lot of transformation in an effort to keep tabs with the ever changing realities of revenue mobilization. Many challenges still stand on the way though and a myriad of solutions are either being implemented of proposed to be implemented to mitigate the challenges. Systems have been put in place to help in revenue administration.

KRA is ISO 9001:2008 certified. Standardization of procedures and predictability of outcomes is of utmost importance to the authority. The KRA $6^{\text {th }}$ Corporate plan enshrines the KRA vision as: 'To facilitate Kenya's transformation through Innovative, Professional and Customer-Focused Tax Administration' and the mission as 'Building Trust through Facilitation so as to Foster Compliance with Tax and Customs Legislation'. The second key thrust in the plan is stated as 'Leveraging technology to enhance service delivery and promote compliance'. It is therefore clear from the foregoing that the greatest focus is on making it progressively easier for the taxpayer to comply and that technology is expected to play a major role in the same.

Ways of doing business keep evolving to suit current realities. Some of the new ways of doing business are exploited by unscrupulous people who seek to make profit without payment of taxes. This paper therefore seeks to make proposals that may be subjected to further discussion in an effort to expand the tax-base in terms of both the quantities and qualities of the taxpayers with respect to the amount of tax paid and adherence to the legal timelines for compliance.

Article 6 of The Constitution of Kenya 2010 specifies the administrative units of the country as consisting of the National Government and 47 County Governments. The central government boasts of established systems and procedures, which have also been and continue to be subject to abuse. The County Governments however are only in their first term of existence, having first come into existence with the March 2013. They have therefore struggled to establish systems in place to safeguard their revenue. A report by the 
controller of budget released in February 2015 indicated that 14 of the 47 Counties collected less local revenues than their predecessor municipal councils in their first year of operation ${ }^{1}$.

The National Treasury has established the IFMIS system as required by Article 227 of The Constitution ${ }^{[3]}$ and Section 12 (1) (e) of The Public Finance Management Act $2012^{[1]}$. Revenues from suppliers paid through the system were however noted to be unsatisfactory. The gap was identified as lack of a direct linkage ${ }^{2}$ between The Treasury's IFMIS system and KRA's iTax system. The DTD RCO therefore set out to manually collect data from the payment vouchers of all the counties and gathered a substantive amount of data on the same. For FY 2014/2015, only Tharaka Nithi County data was not collected. Although it was concluded that the data received from the counties was only part data, the collected data revealed the extent of the problem.

The FY2015/16 data was only collected from 26 counties. It was found that, only 587 (4\%) were regular filers and payers of returns and tax respectively, with total supply value of Kes 1,689,771,597. The remaining 8,260 suppliers were credit filers, untraceable, under-declarations and nil/non-filers and accounted for a total supply value of Kes $42,661,955,440^{3}$.

Attempts to contact these taxpayers have not been fruitful, even for the stations where the PINs are domiciled. After risk-based profiling and case selection, 1,589 cases yielded a total of Kes 1,913,225,582 and actual collection of Kes $737,475,071$ by June 2016. These taxpayers are colloquially referred to as "tenderpreneurs". Most of them have deliberately captured the wrong information in the tax systems to avoid detection, which leads to the reference to them as "briefcase companies" as they have no known physical address.

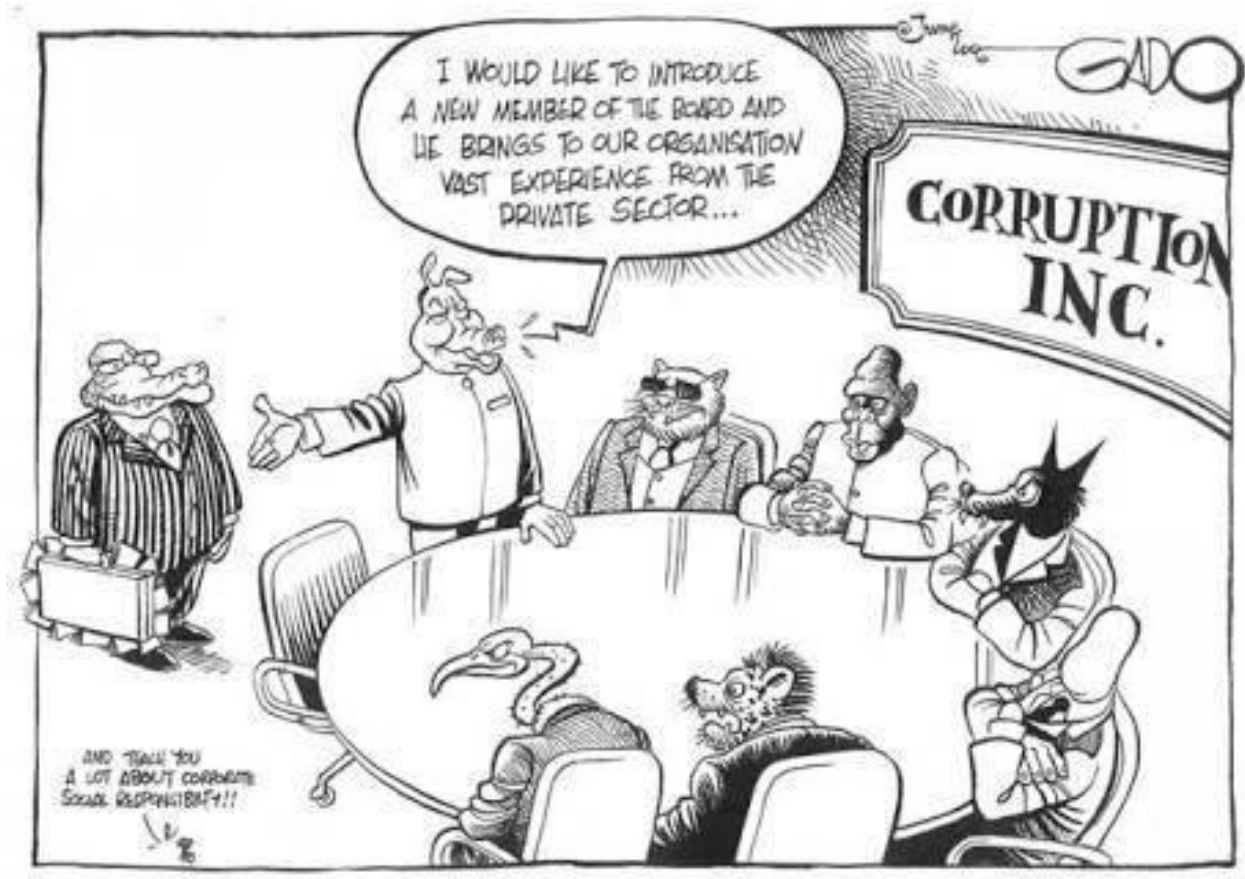

Fig. 1: Tenderpreneurs ${ }^{[4]}$

They are also depicted in newspaper articles as faceless humanoids, pigs, vultures and hyenas as shown in figure 1 above. It is also not rare to hear them referred to as "air suppliers".

The root cause of this problem is therefore corruption. This is exacerbated by the lax checks and controls inherent in the current systems.

${ }^{1}$ Menya, W. (2015, 02 14). Counties Revenue Collection Controller of Budget Report. Retrieved 04 11, 2017, from The Daily Nation: http://www.nation.co.ke/counties/Counties-Revenue-Collection-Controller-of-Budget-

Report/1107872-2624238-11ae7myz/index.html

${ }^{2}$ This has since been done, with effect from January 2017.

${ }^{3}$ Source: DTD Regional Coordination Office County Project.

DOI: 10.9790/0837-2205040817 www.iosrjournals.org 9 9|Page




\section{LITERATURE REVIEW}

Most literature on this subject is found in the media. It is therefore likely to be tinted with innuendo and strong personal opinions. A March 2016 poll by Infotrak ${ }^{4}$ however showed the media to be the most trusted institution in the country ${ }^{[5]}$. Local and international publications have picked up this topic with enthusiasm. Bungoma County is reported to have purchased 10 non-carcinogenic (in their defense), wheelbarrows for a slaughterhouse for Kes 109,000 each ${ }^{[6]}$. The said wheel barrows are available in the market for a paltry Kes 5,000 . The secretive nature of these transactions results in scanty formal information on this subject. The 2013/2014 auditor general's report revealed that up to Kes 66 Billion of the money disbursed to the various government MDAs had no supporting documents (Auditor General, Republic of Kenya, 2015).

The whole subject is what may be referred to as a "public secret". Everybody is talking about it, but nobody wants to be quoted on it. It is said to be deep -rooted in society ${ }^{[7]}$. This whole problem likely exists because of the perceived levels of corruption. The Transparency International corruption Index currently ranks Kenya at position 145 out of the 176 countries in the list with a score of 26 out of 100 (Transparency International, 2016) ${ }^{5}$. This is a very low ranking.

A former EACC chairman (himself hounded out of office on allegations of corruption and conflict of interest) is on record as having told Reuters that the country loses up to a third of its annual budget to corruption ${ }^{[8]}$. Other estimates by ICPAK put the annual figure at Kes 69 billion ${ }^{[9]}$. In November 2015, the President of Kenya, H.E. Uhuru Kenyatta declared corruption a national security threat ${ }^{[10]}$. All companies transacting with government would henceforth be required to sign a code of conduct before transacting business with any government entity. Violators of the conditions would be barred from transacting any business with the government for a period of 5 years.

A supplier was also found to have irregularly done business with the National Youth Service worth Kes 1.6 billion. She reportedly carried money in sacks ${ }^{[11]}$. A similar scam is under investigation by the Senate of the Republic of Kenya on a junior official working as a collections clerk in Bungoma county government whose account suddenly transacted over Kes 315 million in the life of the county government.

A 2016 report by the EACC revealed that counties were the most corrupt with 33 out of 78 corruption cases investigated involving the counties ${ }^{[12]}$. This is consistent with the observation of low tax compliance observed for county government suppliers. Compliance of County Government suppliers is so key to KRA's compliance efforts that it is listed as one of the deliverables under the Authority's vision $2018^{6}$ with required monthly reporting to the board of directors.

Part of the problem with compliance in this sector is lack of adequate KRA presence and secrecy of the transactions. Proposals in this paper take cue from a 1979 study that concluded that humans tend to behave in a pro-social manner when they believe they are being watched (Beaman, Arthur L, Klentz, Bonnel, Diener, Edward, \& Svanum, Soren, 1979) ${ }^{[13]}$. Similar findings were also made in 2012 (Jan M.Engelmann, Tomasello, \& Esther Herrmann, 2012) ) $^{[14]}$ and in 2013 (Callow, Holmes, Roche, \& Nettle, 2013) ${ }^{[15]}$.

\section{PROPOSED APPROACHES}

\subsection{Transaction-Based Income Tax.}

Upon being confronted by KRA, Ignorance is the first line of defense for these taxpayers, despite the common saying, (which is also law ${ }^{7}$ ) that ignorance is no defense. At a county supplier facilitation forum in Kitui County ${ }^{8}$, the participants acknowledged their shortcomings and blamed it on ignorance, even as they pleaded for a tax amnesty. Most of them claimed not to understand what they termed as the "complex tax procedures". They therefore requested for a simplified system where all the tax due would be deducted from their pay at source so that they could "eat their money in peace". There was no mention of returns. This may be a pointer to the real nature of their claim to ignorance. Those that have an idea of filing of returns only associate the exercise with their employment income. These are mostly teachers and other civil servants.

\footnotetext{
${ }^{4}$ A market research company

${ }^{5}$ Transparency International. (2016). Kenya. Retrieved 04 11, 2017, from Transparency International: https://www.transparency.org/country/KEN

${ }^{6}$ KRA Vision 2018

${ }^{7}$ Section 7, Penal Code Cap 63, Laws of Kenya

${ }^{8}$ Held on $12^{\text {th }}$ January 2017 at the Kitui Parkside Villa Hotel and jointly facilitated by KRA and the Kitui County government.
} 
The proposal is therefore to introduce a mandatory flat rate of tax that is final and can be applied for all payments to taxpayers in business. This would in effect be like the operation of PAYE on payroll taxes. For taxpayers with no other source of income, there will be no further tax to pay in the annual tax return. Taxpayers below a determined threshold, say gross income of Kes 50 million per annum (small companies ${ }^{9}$ ) would be registered for this tax. Deduction of tax would be at the point of payment.

The taxpayer would get a special obligation, which is an Income Tax obligation but exempts them from all Withholding Income Tax and Withholding VAT deduction. Having such an obligation should not remove the taxpayer from the Income Tax Obligation, like the TOT does. Employees with business may therefore get the obligation. This would therefore be made known to the procuring entity that will be expected to process payments to the taxpayer at the point of tendering.

The tax is a final withholding tax and the taxpayer does not need to file a return, as the system compiles that information and auto-generates an annual return for the taxpayer once the financial year ends. This would also be a selling point for KRA to the taxpayers by enabling them to generate books of account for their business that have been developed and are maintained by KRA free of charge at any time.

The iTax system may be enabled to generate a financial statement for the taxpayer immediately their financial year ends. The statement may be in the form of an official letter from the commissioner thanking the taxpayer for their contribution to nation building through active engagement in business. It may be modeled along the line of the letter by a board of directors to the shareholders of a company, only that in this case it will have a personalized reference to the taxpayer.

The Financial year may remain to be $1^{\text {st }}$ January to $31^{\text {st }}$ December of each year for individuals ${ }^{10}$ and optional for non-individuals. No new obligation should be added within the year. Registration for or deregistration from all such obligations should either be post-dated to the beginning of the next financial year or back-dated to the beginning of the current financial year ${ }^{11}$.

This tax head shall not be available to non-residents.

\subsubsection{Rate of Tax}

The proposed rate is $20 \%$ of the gross transaction amount.

\subsubsection{Justification/Basis}

This will be approached from both the assumption that if the taxpayer was fully compliant, they would pay both Income Tax and VAT. The sum of the relative contribution of each tax head to the total gross transaction amount forms the basis for the proposed rate of tax.

\subsubsection{VAT}

For every Kes 100 of gross transaction amount (including VAT at 16\%) charged by a supplier of taxable supplies, Kes 13.79 is VAT charge:

$$
\frac{100}{116 \%} \times 16 \%=13.79
$$

This means that $13.79 \%$ of every taxable supply value may be taken to be VAT chargeable by the supplier. KRA aims to raise the VAT to GDP ratio to $9 \%$ by June $2018^{12}$. It is therefore safe to assume that $9 \%$ of the supply value is payable to the government as VAT, considering the input tax deduction.

The implication then of the rate proposed in 6.1.1 above is that the taxpayer is paying Kes 20 as tax for every Kes 100 of gross supply value. With Kes 13.79 being VAT charged as per equation (1) above, the taxable amount, we are left with is Kes 86.21 being the taxpayer's turnover for the transaction:

$100-13.79=86.21$

This is the taxable amount for VAT purposes. With the proposed Kes 20 per Kes 100 tax rate and the preferred VAT to GDP ratio of $9 \%{ }^{[16]}$, the taxpayer will be paying Kes 11 Income Tax out of every Kes 86.21 of taxable value of transaction:

\footnotetext{
${ }^{9}$ As Defined by Section 624(3) of the Companies Act 2015, i.e. satisfies at least two of the following conditions: 1. Turnover is less than Kes 50 million 2. The value of the net assets on its balance sheet is not more than Kes 20 million 3. Has less than 50 employees.

${ }^{10}$ Section 27(3) Income Tax Act Cap 470 Laws of Kenya

${ }^{11}$ Much like Regulation 4 of the Income tax (Residential Rental Income Tax) Regulations, 2016 - Legal Notice No. 106 of $9^{\text {th }}$ June 2016, Laws of Kenya.

12 From the KRA Vision 2018 Document and the KRA $6{ }^{\text {th }}$ Corporate Plan.

DOI: $10.9790 / 0837-2205040817 \quad$ www.iosrjournals.org $11 \mid$ Page
}


$20-9=11$

The effective Income Tax rate in the transaction is therefore $12.76 \%$ as found in equation (4) below:

$\frac{11}{86.21} \times 100 \%=12.76 \%$

The denominator of equation (4) above is picked from equation (2) since the design of VAT is such that it is not a cost to the taxpayer. The business bears the impact of the tax while the incidence is on the customer, in this case the paying entity.

This is an equitable rate and comparable to the $10 \%$ rate charged for the MRI. The $2.76 \%$ premium on it will serve as an encouragement for the taxpayer to formalize their transactions

\subsubsection{Income Tax}

The highest rate of tax for individuals is $30 \%$. The effective rate of tax for the income asymptotically approaches this rate as the income increases as shown in figure 2 below. This is higher than the proposed rate for this tax. It is worth noting that the said rate is on profits and not on the gross transaction amount like the proposed Transaction-Based Income Tax. Input costs have therefore been considered on the same. The tax to GDP ratio for Kenya also currently stands at $22 \%{ }^{13}$. This proposed rate is therefore concessionary in a way. During the 2015/2016 tax amnesty on rental income, the taxpayers were allowed an empirical deduction rate of $40 \%{ }^{14}$ of the gross income as expenses. Assuming the balance was the top slice of income $e^{15}$ and taxed accordingly on the graduated scale, the taxpayers had an effective tax rate of $18 \%$ on their gross income. A rate slightly higher than the value of the tax to GDP ratio is necessary to prompt the taxpayers to formalize their processes and procedures. The rate should however not be outrageously high. The taxpayer is expected to realize that they are paying a premium for their option of the simplified tax regime of TBIT and take it as a motivation to either learn the formal procedures or hire professionals to do it for them ${ }^{16}$.

This proposed rate may however be introduced at a lower rate on pilot.

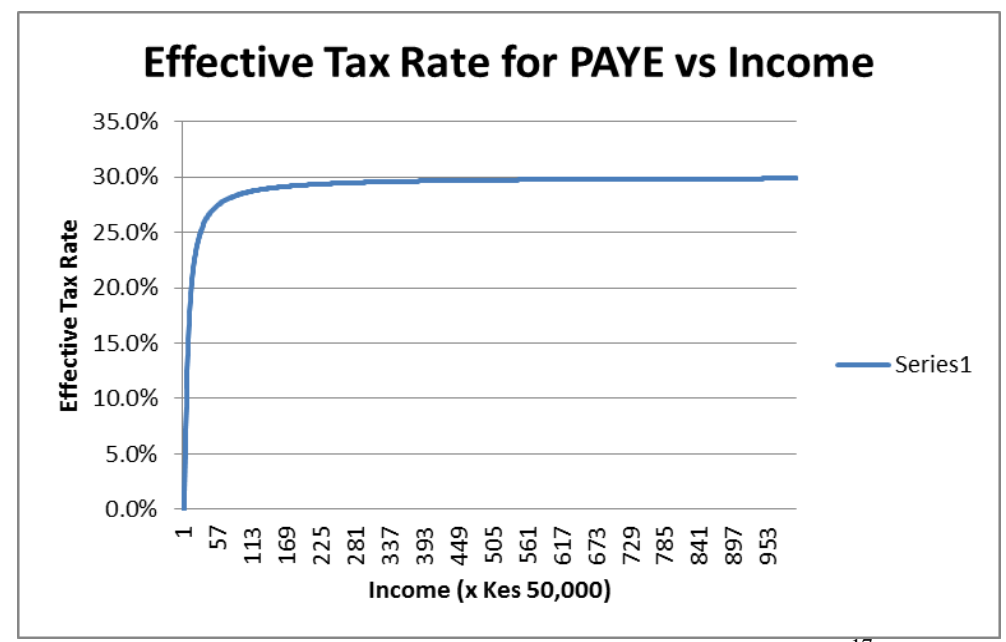

Fig. 2: PAYE Effective tax rate vs Annual Income ${ }^{17}$

\footnotetext{
${ }^{13}$ Price Waterhouse Coopers, Transfer pricing and developing countries - Kenya, Appendix D: Country Study Kenya p.9

${ }^{14}$ Source: KRA Real Estate Sector Office

${ }^{15}$ As defined under Section 34(1B) of the Income Tax Act cap 470 Laws of Kenya. That part of the income that attracts the highest rate of tax.

${ }^{16}$ Under Section 21 of the Tax Procedures Act 2015 Laws of Kenya, only a registered tax agent or a legal practitioner in his/her normal course of business may represent another person of offer tax assistance for pay.

${ }^{17}$ Based on PAYE rates in force before $1^{\text {st }}$ January 2017 


\subsubsection{Deviation from similar tax heads}

This tax may be loosely related to MRI ${ }^{[17]}$ and TOT. There are however subtle differences that differentiate it.

\subsubsection{Deviation from RRI (MRI Tax)}

Contention may arise on the comparable lower rate of tax applied to the MRI tax. The same is taxed at a rate of $10 \%$ of gross income and is also final ${ }^{18}$. It sets a range of application of the tax for incomes between Kes 144,000 - Kes 10,000,000 per annum. The rate for MRI can be justified by the high input costs required for putting up rental income. Capital deductions would therefore be expected to be a lot even in the formal regime and the effective tax rate lower. This is only an assertion though. In addition to the foregoing, residential rental income is exempt from VAT. The taxpayers therefore do not charge or account for VAT on the income received. The TBIT should therefore be higher than the MRI rate of $10 \%$ by the determined VAT rate for businesses making taxable supplies.

\subsubsection{Deviation from TOT}

The proposed TBIT bears similarity to TOT, albeit with a different much higher rate of tax. TOT is a tax imposed mostly on shop owners and was initially targeted at the lower end informal sector. The TOT taxpayers are expected to file returns and pay tax quarterly. In this case of TBIT, the taxpayer does not need to have a fixed place of business and won't need to file any returns; the system will automatically send them annual statements, showing the business volumes transacted and the tax paid. TOT is also on gross sales for a quarter while the TBIT is taxed on each transaction, with the tax so charged being final and not contingent on any other transaction.

\subsubsection{Expected Outcome}

This tax will help on three fronts:

1. Guarantee government of minimum collection of tax from the category of taxpayers supplying government. This in effect means that the paying entity will be subjected to the Withholding Tax Rules ${ }^{[18]}$ and must therefore participate in securing the tax as the taxpayer's corporate gatekeeper for tax due.

2. Simplification of tax processes and procedures, resulting in lower compliance costs for the taxpayers.

3. Taxpayer education for the suppliers. By seeing a direct cost of tax on their supplies, the taxpayers will learn to associate income with taxes and seek to learn more ways of involvement to reduce their tax liability. The expectation is that they learn enough to request to be moved to the formal regime.

From the 26 counties alluded to above, it is clear that tax was not paid on Kes 42,661,955,440. At the proposed TBIT rate, KRA would have collected Kes 8,532,391,088.

\subsubsection{Possible limitations and disadvantages of this tax}

This tax will change from an indirect expense to a direct cost on the business. The taxpayers may want to pass on this cost to the purchasers and therefore make their supplies more expensive to retain their original margins. This is however expected to be mitigated by those in the formal regime who will have no such reason for over-pricing their goods. Additionally, a lot of foreign companies operate in Kenya, being subjected to $20 \%$ withholding tax rate on contractual fees, yet having out-bided local companies who are subjected to $3 \%$ withholding tax on the same transaction. The risk for increased costs of supplies solely on the basis of the Transaction Based Income Tax will therefore be likely very low. The suppliers subjected to this tax may feel like they have been unfairly targeted with higher costs. Responses to such assertions will however serve as taxpayer education forums for the same, which is needed anyway.

\subsection{Class Certification for taxpayers \\ 3.2.1 Kenyan context}

An individual taxpayer or small company ${ }^{19}$ will automatically qualify and get registered for TBIT unless they are registered as what we may refer to as "Class A" taxpayers. Registration for Class A, which will enable them operate in the formal regime as they currently are will depend on several factors which in the opinion of the commissioner imply that the taxpayer's risk profile is manageable. These may include:

\footnotetext{
${ }^{18}$ Section 6A Income Tax Act (As Amended by Finance Acts 2015 and 2016).

${ }^{19}$ As Defined by Section 624(3) of the Companies Act 2015, i.e. satisfies at least two of the following conditions: 1. Turnover is less than Kes 50 million 2. The value of the net assets on its balance sheet is not more than Kes 20 million 3. Has less than 50 employees.
}

DOI: 10.9790/0837-2205040817 $\quad$ www.iosrjournals.org $\quad 13 \mid$ Page




\subsubsection{Evidence of operation and compliance with the various tax laws}

There must be evidence of operation and compliance with the various tax laws for a period of at least 3 years. Businesses that are less than a year old should not be considered at all. The business must have obtained a Tax Compliance Certificate for each of the preceding three years it was in operation. The number 3 is empirical but may be loosely associated with the findings of a 2015/2016 study by the KRA TCRM unit which revealed that a majority of the non-filers for VAT are businesses aged between 2-6 years. The period may be further negotiated.

\subsubsection{Execution of a bond}

The taxpayer will need to execution of a bond equivalent to $20 \%$ of the business turnover in line with the proposed TBIT rate. This is not a new concept and is applied in Customs ${ }^{[19] .}$ The taxpayer may therefore not be allowed to do business in excess of 5 times the value of the active bond at any time. Active bond in this case would be the value of a bond that is not committed to a supply. If for instance the supplier has a total bond of Kes 1 million and he makes supplies of Kes 2 million, he has only committed Kes 400,000 of his bond. He may therefore engage in further business of up to Kes 3 million.

When the taxpayer is paid for their supplies, they apply to the commissioner for the amount of bond that secured the transaction to be released. Where it is found that the tax due was not paid, the commissioner then simply calls the bond from the bank or insurance company that did the underwriting. Since it is known that banks would rarely give credit facilities to a person they cannot trace, this will be a surety for the commissioner and the bank will serve as a gatekeeper for the taxpayer. Additionally, the bank will come in conveniently by limiting the amount of surety a person may get by employing their vast experience and tacit knowledge of risk profiling to develop a proper risk profile of the taxpayer and appropriately cap the bond amount available. This would spare the government the embarrassment of a hairdresser being allowed to supplies that would normally not be available to a large corporate body ${ }^{20}$. A person may obtain a syndicated bond, whereby he may approach several institutions to jointly or severally issue him with a bond. Where a taxpayer has had a bond called up by the commissioner, they are withdrawn from "Class A" and may not be "Class A" for a period of 5 years.

A further advantage for this system is that it secures government revenue ab initio. This is of great advantage to instances where there is suspected fraud. The existence of a surety bond also means that a financial institution was involved at some point and the "tenderpreneurs" may not be absolutely faceless. Possession of a "Class A" certificate is likely to be a source of pride for the taxpayers. Eventually, it is expected that some companies may prefer dealing only with "Class A" taxpayers and thus enable taxpayers to check on each other as each other's corporate gatekeepers.

The process flow for the bond proposed above is illustrated in figure 3 below.

Another advantage of the bond is that it will keep refreshing the memory of KRA to the taxpayer. Humans tend to behave in a pro-social manner when they know they are being observed. They are therefore likely to follow the rules in place and comply (Beaman, Arthur L, Klentz, Bonnel, Diener, Edward, \& Svanum, Soren, 1979) ${ }^{[13]}$. KRA does not need to be physically present for the taxpayers to comply, regardless of the behavior of other tenderpreneurs (Callow, Holmes, Roche, \& Nettle, 2013) ${ }^{[15]}$ as the bond is its eyes, ever looking at the taxpayers.

\subsubsection{Concept Origin}

This said "Class A" taxpayer certificate is modeled along the Swedish F-tax. This is a type of certificate that self-employed persons apply for before transacting their business. A person with an F-tax commits to paying their own tax and social security contributions. Where another person transacts with a selfemployed person who does not have the F-Tax, they become liable for the taxes and social security contributions of the other party.

An example is where a company hires a consultant without an F-Tax. The company will have to deduct the tax and social security contributions from his pay and give him the difference as they remit the deductions to the government. If the consultant had the F-Tax, the company would pay him all the money and he would make the remittances himself to the government. The F-Tax may be withdrawn. Companies prefer dealing with people with the F-Tax, although it is not mandatory. This is because their transaction costs and time will be reduced. F-Tax certification is also a sense of pride for the taxpayers and they quote it in their business documents.

\footnotetext{
${ }^{20}$ A hair dresser is reported to have supplied goods worth Kes 791 Million to the National Youth Service of Kenya. 


\subsection{Staggered submission dates for tax returns}

\subsubsection{Manifestation of the problem}

A question may be posed: Does a taxpayer who had absolutely no transactions need six months to file their tax returns? The law gives 6 months ${ }^{[20]}$ for taxpayers to file their final return of income for the past year. Any balance of tax should however have been received by KRA on or before the last day of the fourth month following the end of the accounting period ${ }^{[20]}$. This therefore fixes this date as 30th April for individuals, seeing that their legal accounting period end date is 31 st December ${ }^{[20]}$.

Despite the six months allowed, most taxpayers still wait for the very last days to file their returns. Some of these are NIL returns. The taxpayers therefore unnecessarily jam the system and make it harder for the quality taxpayers to comply with their legal obligations.

\subsubsection{The solution}

This solution would be applied to the taxpayers who choose to remain in the formal regime for making books of account. KRA would start the campaigns early so as to benefit from a collective taxpayer education move. It is expected that such a staggered due date strategy for filing tax returns will keep the taxpayer population abreast with their records. KRA will also be forced to engage in early campaigns for filing tax returns to the benefit of the taxpayers. The systems will also have a well spread out load and therefore reduce the chance for system downtimes as is normally experienced during the last week of June when most people want to file their returns.

\subsubsection{First Group}

A taxpayer with no income should only have 60 days to file their tax return. Their due date should be fixed to the last day of February of the subsequent year. At the end of the year, the system should send mails to all taxpayers reminding them of this early due date for all taxpayers without income to declare. Default penalties should be similar to those of other taxpayers as specified under the Tax Procedures Act $2015^{[21]}$.

\subsubsection{Second group}

Taxpayers with tax to pay should have their tax filing dates synchronized with the dates for payment of the balance of tax. This is the last day of the fourth month following the end of the accounting period. This will assist the taxpayers who plead ignorance when the system penalized them after they file their returns between 30th April and 30th June with a debit tax balance.

\subsubsection{Third group}

Taxpayers with transactions to declare but either zero tax to pay or a credit balance may then be allowed until the last day of the sixth month following the end of the accounting period to file their returns. These have no positive revenue implications for the authority and may be allowed to file last.

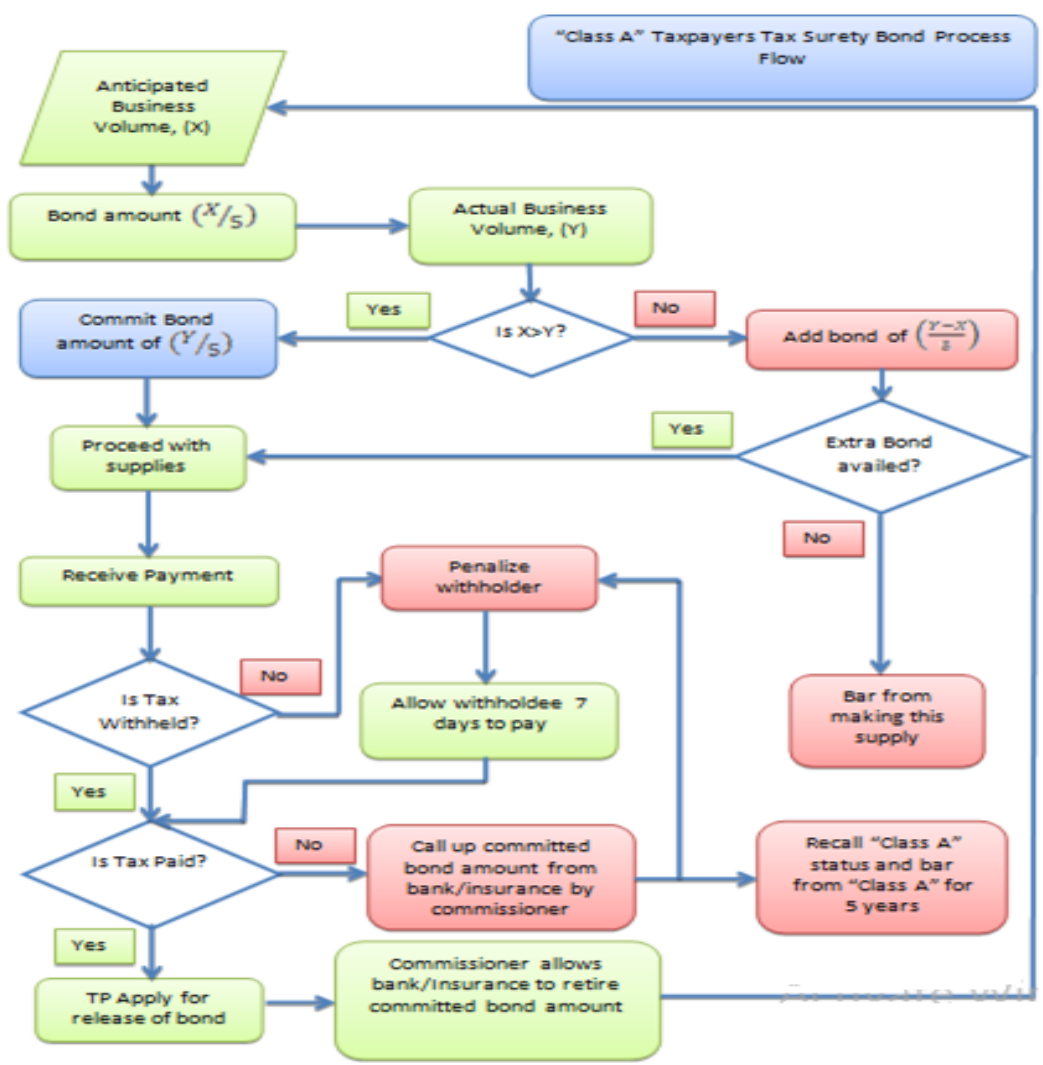

Fig. 3: Process flow for the tax bond 


\subsection{Legal}

\section{IMPACT ANALYSIS}

The proposals in this paper are not immediately implementable. Sweeping legal provisions have to be provided for before operationalization. Proper distinction has to be made between the proposed tax and TOT. A definition of "small company" has to be included in the tax laws, either on its own, or preferably adopting that of the Companies Act 2015. The commissioner has to be empowered to demand a tax surety bond before a business can supply the government in addition to being empowered to call up a bond together with penalties and account for the same as tax paid. This particular angle must be carefully planned and all necessary laws amended as necessary before even a pilot can begin.

\subsection{Political}

Amendments to tax laws are traditionally reserved for the annual budget cycle. This implies that any good proposal made at any other time has to wait for the whole cycle before implementation. A lot of lobbying may also be required for taxpayers who are politicians and may feel targeted by the proposals contained herein. All government entities that would be involved would have to be lobbied to provide goodwill and backing for such an endeavor. Classification of taxpayers may be misunderstood to mean the government is discriminating against start-ups or small businesses. This can be mitigated by a carefully planned marketing strategy to enable the public understand where the problem is and the importance of having everyone paying their fair share of taxes. The focus may be placed on the low compliance levels in this sector of the economy compared the combined large volumes transacted by the same.

\subsection{Operations}

All technical staff will have to be trained to run the whole program and explain to taxpayers the "Class A" certification. Staff will need to have the understanding of the intended purpose of the law and act accordingly in terms of giving the taxpayer all relevant information. The iTax system would need to be adapted to act as envisioned. This will cost the Authority money for system development.

\subsection{Business}

Taxpayers who trade with the government will feel the impact of this tax. With sustained lobbying, the larger LTO and MTO companies should also end up only dealing with suppliers who are "Class A" certified, because such will show trust by the government and therefore goodwill. Where a withholder fails to withhold, they will only be subject to the penalties under Rule 14 of the Income Tax (withholding Tax) rules and pay $10 \%$ of the un-withheld amount. They will not be required to pay up the tax in an agency setting, since the commissioner will now be able to call up the tax amount from the committed bond.

\subsection{Doing business index}

If these proposals are flawlessly rolled out, they are capable of making the cost of compliance much lower in terms of time and money. If however they are not, a fall-out may ensure, where the taxpayers will not understand the new tax and will resist it. They are therefore likely to feel like the procedures have been complicated and more tax is needed from them.

\section{CONCLUSION}

The proposals in this paper cover areas that have been identified by the taxpayers as areas of pain. These are mainly complexity of tax procedures and lack of knowledge. On KRA's part, it is thinness on the ground, thus lack of appropriate visibility. These can be tried on pilot. They however require legal amendments to be applicable. They are therefore long term solutions to the problem at hand. More rigorous impact assessment and risk analysis needs to be done on these proposals to ensure they are "water-tight". Being very radical, a proper marketing and change management strategy may be needed in the rollout of such modus operandi. This paper was a desk research and may therefore not capture the accurate picture on the ground. Field studies need to be conducted to verify applicability of the proposals and gauge the taxpayers' reactions to the same.

\section{REFERENCES}

[1] The Public Finance Management Act, 2012, Laws of Kenya

[2] Auditor General, Republic of Kenya. (2015). Report of The Auditor General on the Financial Statements for National Government for the Year 2013/2014. Nairobi: Auditor General, Republic of Kenya.

[3] The Constitution of Kenya, 2010 
[4] Gado. (2016, 04 18). Jukwaa Proboards. Retrieved 04 12, 2017, from Jukwaa Proboards: http://jukwaa.proboards.com/thread/9491/bankers-kenya-declare-war

[5] Ngetich, J. (2016, 02 14). Survey: Media The Most Trusted Institution. Retrieved 04 12, 2017, from The Standard Media Group: https://www.standardmedia.co.ke/article/2000196323/survey-media-themost-trusted-institution

[6] WANJALA, R. (2015, 09 09). Uproar as Bungoma spends Sh1m on 10 wheelbarrows. Retrieved 04 13, 2017, from Daily Nation: http://www.nation.co.ke/counties/Bungoma/Uproar-Bungoma-Sh1mwheelbarrows/1183258-2863512-12sx12dz/index.html

[7] David, M., \& Faith, K. (2009, 04 23). Book on Kenya corruption spirited into country. Retrieved 0413 , 2017, from CNN: http://edition.cnn.com/2009/WORLD/africa/04/23/kenya.corruption.book/ index.html?_s= PM:WORLD

[8] Muriri, D. (2016, 03 10). Third of Kenyan Budget lost to corruption: anti-graft chief. Retrieved 0411 , 2017, from Reuters: http://www.reuters.com/article/us-kenya-corruption-idUSKCN0WC1H8

[9] Kithi, N. (2014, 10 10). Kenya loses Sh 69B annually to corruption. Retrieved 04 13, 2017, from The Standard Media Group: https://www.standardmedia.co.ke/article/2000137672/kenya-loses-sh69bannually-to-corruption

[10] PSCU. (2015, 11 23). President Uhuru Kenyatta declares corruption a national security threat. Retrieved 04 11, 2017, from The Standard Media Group: https://www.standardmedia.co.ke/article/2000183336/ president- uhuru-kenyatta- declares-corruptiona-national-security-threat

[11] Psirmoi, D., \& Wilfred, A. (2016, 11 02). Dodgy Josephine Kabura angers MPs in NYS probe. Retrieved 04 11, 2017, from The Standard Media Group: https://www.standardmedia.co.ke/article/ 2000221808/dodgy- josephine-kabura-angers-mps-in-nys-probe

[12] Njagi, J. (2016, 11 07). Counties most corrupt, shows EACC report as billions lost. Retrieved 0413 , 2017, from Daily Nation: http://www.nation.co.ke/news/1056-3443220-5goyhqz/

[13] Beaman, Arthur L, Klentz, Bonnel, Diener, Edward, \& Svanum, Soren. (1979). Self-awareness and transgression in children: Two field studies. Journal of Personality and Social Psychology.

[14] Jan M.Engelmann, Tomasello, M., \& Esther Herrmann. (2012). Five-Year Olds, but Not Chimpanzees, Attempt to Manage Their Reputations. Public Library Of Science.

[15] Callow, L., Holmes, J. R., Roche, M. L., \& Nettle, D. (2013). Do Images of 'Watching Eyes' Induce Behaviour That Is More Pro-Social or More Normative? A Field Experiment on Littering. Public Library of Science.

[16] KRA Vision 2018 Document

[17] Income tax (Residential Rental Income Tax) Regulations, 2016 - Legal Notice No. 106 of 9th June 2016, Laws of Kenya.

[18] Income Tax (Withholding Tax) Rules, 2001, under the Income Tax Act cap 470 Laws of Kenya.

[19] The East African Community Customs Management Act 2004 Sections 106 - 109.

[20] Income Tax Act, Cap 470 Laws of Kenya, Sections 52B, 34(1B), 6A, 92A, 27(3).

[21] Tax Procedures Act 2015, Laws of Kenya Sections 21, 83. 